\title{
GREEN CONTROLLING IN SMALL AND MEDIUM-SIZED AGRICULTURAL ENTERPRISES
}

\section{Ludmila DOBOŠOVÁ1; Daniela HUPKOVÁ2; Petronela ŠVIKRUHOVÁ ${ }^{3}$}

\author{
${ }^{1}$ Slovak University of Agriculture in Nitra, Faculty of Economics and Management, Department of \\ Accounting \\ ${ }^{2}$ Slovak University of Agriculture in Nitra, Faculty of Economics and Management, Department of \\ Economics \\ ${ }^{3}$ Slovak University of Agriculture in Nitra, Faculty of Economics and Management, Department of \\ Management
}

\begin{abstract}
The art of controlling consists in predicting changes within the company, evaluating the identified changes and then proposing appropriate processes and approaches. One of the changes to which controlling must respond is the constantly increasing importance of environmental aspects at the company level, which is becoming a cross-sectional element of every functional area of the company. In recent years, the term "green controlling" has become increasingly common. It can be defined as a management supporting function that leads to that planning, management and control in the company include the so-called "Green content". The research study is focused on the evaluation of the approach of small and medium-sized agricultural enterprises in Slovakia to the ecological aspects of business, which is promoted by green controlling. In order to obtain objective information, an empirical research was realized - a questionnaire survey supplemented by interviews with representatives of selected agricultural entities. The results of the research study indicate that although the topic of environmental sustainability in business has become increasingly important in recent years, environmental aspects are not really integrated into corporate management. Many green controlling tools are unknown to representatives of selected companies. Farms prioritize achieving economic goals and environmental goals remain aside. The limiting factor of the research is the considerable ignorance of the agricultural holdings representatives about the ecological aspects entering into the management of the company, as well as their negative approach.
\end{abstract}

Key words: agricultural enterprises; green controlling; management; sustainability

\section{Introduction}

Environmental protection and environmental sustainability are becoming crosscutting elements of every functional area of business management. External stakeholders are increasing interest not only in financial information and information on economic performance, but also in information on the company's environmental focus. In this regard, controlling plays an important role in integrating sustainability components into corporate goals and corporate activities in management, planning and control. Controlling processes and tools should be extended to include ecological orientation.

Green controlling is a body that supports and raises awareness of company management and employees in environmental issues. It identifies ecological

https://doi.org/10.11118/978-80-7509-820-7-0245

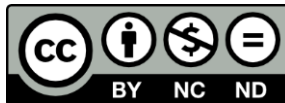


information requirements, collects them, selects relevant ones and analyzes these data. The collection of environmental information is essential for determining environmental performance and identifying opportunities and risks. Then it interprets this information to the company's management in the form of reports, which should include data processed into goals or key figures so that they can be integrated as target values into all information and decision-making processes of the company.

\section{Literature review}

The issue of ecological sustainability has gained great importance in science and practice in recent years (Horváth 2018, p. 612; Isensee, Michel 2011, p. 436). Due to the growing reflection of stakeholders (e.g. investors, customers and nongovernmental organizations) on sustainable business performance, the topic of sustainability has developed into a factor of strategic success in recent years (Michel, Isensee, Stehle 2014). In order to implement sustainable corporate governance, companies face the challenge of harmonizing economic, environmental and social goals (Isensee, Michel, 2011, p. 436). Environmental aspects can affect the economic success of companies. In most cases, however, environmental factors are not yet truly integrated into corporate governance. It is time to link environmental management and controlling more closely and to embed environmental factors in the planning and remuneration system (Günther, Günther, Endrikat, 2018, p. 34).

Controlling as a management service has to follow changes in management's activity and become proactive driver of innovation. Controllers and the management have a joint responsibility to reach the objectives because they help design management process. The importance of innovation for company's sustainability impacted also the practice of controlling. As a management service which provides transparent information for decision making process, controlling has to follow management's focus and activities (Vitezic, Vitezic, 2015, p. 176). Since human activities have transformed the biosphere, leading to global climate change, biodiversity loss and various types of pollution, 'green' or sustainability controlling has been developed to support management in the face of new challenges (Bedenik et al. 2019, p. 23). There is a variety of terms used to name "green controlling" such as environmental controlling, ecologically oriented controlling, ecological controlling, eco-controlling etc. The concept is widely spread and accepted in German-speaking countries, whereas the Anglo-American scholarly community conceptualizes "environmental management control systems" or "environmental management accounting" (Păunică, Mocanu 2017, p. 1137).

Green controling has an active role that goes beyond aspects of economy and economic indicators, and is increasingly focused on sensitizing, consulting and motivating management and other decision makers by constantly reviewing the environmental consequences of individual activities and business decisions. This 
also means the expansion of controller tasks in the direction of green goals and information (Bedenik et al. 2019, p. 23). The objective of sustainability controlling is the comprehensive support of sustainability management, namely formulating and implementing a corporate policy that comprehensively covers all three dimensions of sustainability - people, planet, and profit (Păunică, Mocanu 2017, p. 1137). The managers of an economic entity may use the data regarding the physical consumption and the costs displayed by environmental management accounting in order to adopt decisions having impact both upon the financial performance of the economic entity and upon the environment (Vasile, Man 2012, p. 570). A considerable barrier to the use of sustainable management are also high costs of implementation of pro-ecological and pro-social solutions in enterprises (Pabian, Pabian 2014, p. 105).

Among the intensively discussed issues is whether it is financially advantageous to focus on environmental and social performance. Supporters argue for access to better resources, more efficient resource management, additional business opportunities and cost savings through more efficient use of resources. Critics, on the other hand, point to the additional costs of sustainability management (Greiling, Ther 2010, p. 39). Changes in interests outside the company and within the company mean that the ecological design of the company's activities is no longer perceived only as a cost factor but is also used as a means to improve the company's image. It recognizes the awareness that adequate consideration of environmental goals is a basic prerequisite for the long-term success of society in addition to the economic and social dimension of sustainability (Horváth, Isensee, Michel 2012, p. 50).

\section{Methodology}

The outputs presented in this article are the result of a pilot survey of an extensive research study. The aim of this paper is to evaluate the approach of small and medium-sized agricultural enterprises to the implementation of environmental aspects in management of the enterprise, which promotes green controlling. In order to obtain objective information, an empirical research was carried out - a questionnaire survey supplemented by interviews with representatives of selected agricultural entities. The basis for creating a questionnaire, the results of which formed the basis of empirical research, was the collection of theoretical knowledge in the field of green controlling. We focused on foreign studies and scientific publications dealing with similar issues.

The subject of the investigation was small and medium-sized agricultural holdings. Small and medium-sized enterprises in Slovakia make up a decisive share of the total number of business entities and are one of the basic preconditions for the healthy economic development of the country. This statement is also confirmed by studies (Pletnev, Barkhatov 2016, p. 185; Yoshino, Taghizadech-Hesary 2019, p. 342; Stanciu 2014, p. 255; Mura, Buleca 2014, p. 905; Dobrovič 2015, p. 594). The 
primary technique of data collection was a questionnaire, which was created and distributed to farms using an internet application at the beginning of the year 2021 . The return rate of the questionnaires was at the level of $27 \%$, i.e. 67 completed questionnaire forms. Corporate managers (managers, directors, heads of economic departments, controllers, accountants) were asked to fill in the questionnaire.

The introductory part of the questionnaire contained the so-called classification questions that approached the structure of the research sample in terms of number of employees, legal form of business, length of market presence and foreign capital participation. The main part of the questionnaire consisted of questions aimed at obtaining information on the approach of agricultural enterprises to the implementation of environmental aspects in business management. Common mathematical methods supplemented by descriptive statistics and graphical representations were used to evaluate the questionnaire. The statistical method - Chisquare test was also used, which is aimed at determining the dependence between the studied phenomena. In order to clarify and supplement the information obtained through the questionnaire, we also used the method of interview. We tried to obtain reliable information directly from the source. Business managers from three farms answered the questions we tried to better understand the answers of the respondents in the questionnaire. To the questions we tried to better understand the answers of the respondents in the questionnaire, business managers from three farms answered.

Table 1 Structure of the researched enterprises

\begin{tabular}{l|l|c|c}
\hline \hline Classification criteria & Enterprise category & Total & Relative \\
\hline \hline \multirow{2}{*}{ Legal form of business } & Collective & 23 & $34 \%$ \\
\cline { 2 - 4 } & Limited liability company & 44 & $66 \%$ \\
\hline \multirow{2}{*}{ Size of business } & Small business & 31 & $46 \%$ \\
\cline { 2 - 4 } & Medium-sized business & 36 & $54 \%$ \\
\hline \multirow{3}{*}{ Length of market presence } & Less than 5 years & 5 & $7 \%$ \\
\cline { 2 - 4 } & More than 5 years & 37 & $40 \%$ \\
\cline { 2 - 4 } & More than 15 years & 16 & $24 \%$ \\
\hline \multirow{2}{*}{ Foreign capital } & with foreign capital & 51 & $76 \%$ \\
\cline { 2 - 4 } & without foreign capital & \multicolumn{2}{|l}{} \\
\hline \hline
\end{tabular}

Source: our processing

\section{Results and discussion}

Through a questionnaire survey supplemented by interviews with selected agricultural entities, we found out what is the approach of small and medium-sized agricultural enterprises to issues of sustainability in management and also whether agricultural enterprises apply some elements of ecological controlling. 


\section{Perception of green controlling by small and medium-sized agricultural enterprises}

Based on the questionnaire structure with the initial questions we tried to find out whether management of agricultural enterprises understands what the term green controlling includes.

We wanted to find out if they knew the concept of green controlling. From a research sample of 67 entities, 41 entities answered this question.

Most of the respondents who answered this question expressed a clear opinion that green controlling means management that supports ecological elements in business. Some respondents answered in more detail that this is planning and control, aimed at minimizing negative impacts on the environment.

Among all respondents, there was also found some which have expressed their disagreement to the green controlling. Based on their answer we could state, that they named it only as a modern expression that hardly anyone understands and in which there is nothing substantial.

We expanded the research of this area by another question and we surveyed the respondents about their opinion on what the green controlling content includes, respectively which activities or processes. Based on the study of professional literature, we formulated six partial activities, which are the subject of green controlling

Respondents were asked to rate the importance of performing these activities on a scale of zero to five. Respondents gave the highest weight to the activity, which is focused on providing key data for planning, control and management, whereby green controlling ensures transparency in environmental issues. For almost the same important green controlling activity respondents consider the monitoring of achievement of set environmental goals and compiling reports. The respondents gave the lowest weight to the activity aimed at adapting management processes in the company to green problems. This results from the nature of controlling itself, which is only an advisory body to management and does not have the power to act and make decisions.

Table 2. Tasks of green controlling

\begin{tabular}{lccccc}
\hline \hline & Modus & Median & Average & Min & Max \\
\hline \hline $\begin{array}{l}\text { Demonstrate and ensure the } \\
\text { economic efficiency of the } \\
\text { company`s }\end{array}$ & 3 & 3 & 3,66 & 3 & 5 \\
ecological orientation & 5 & 5 & 4,85 & 4 & 5 \\
\hline $\begin{array}{l}\text { Monitoring the achievement of set } \\
\text { environmental goals }\end{array}$ & & & & & \\
\hline
\end{tabular}




\begin{tabular}{|c|c|c|c|c|c|}
\hline $\begin{array}{l}\text { Promote transparency on green } \\
\text { issues through key data for } \\
\text { planning, control and } \\
\text { management }\end{array}$ & 5 & 5 & 4,93 & 4 & 5 \\
\hline $\begin{array}{l}\text { Identifying key factors for } \\
\text { achieving the so-called "green } \\
\text { success" }\end{array}$ & 4 & 4 & 3,66 & 3 & 5 \\
\hline $\begin{array}{l}\text { Support for the implementation of } \\
\text { "green aspects" in the company's } \\
\text { strategy }\end{array}$ & 4 & 4 & 4,24 & 3 & 5 \\
\hline $\begin{array}{l}\text { Adapt management processes in } \\
\text { the company to green problems }\end{array}$ & 3 & 3 & 2,75 & 2 & 4 \\
\hline
\end{tabular}

Source: own processing

In table 3 are presented respondents' opinions on the activities for which the controller should be responsible. In general, the controller is responsible for providing information to the value chain. This definition is also confirmed by the answers of the respondents. According to them, in the performance of its function, the controller has the responsibility for providing information on green issues to the company's management. Bedenik (2015, p. 161) also confirm that sustainability reporting is a new controlling task. In addition, controller should actively advise stakeholders on controversial environmental issues and should raise the awareness of the company's management about promoting green aspects in business.

Table 3. Responsibility of controllers

\begin{tabular}{llcccc}
\hline \hline & Modus & Median & Average & Min & Max \\
\hline \hline $\begin{array}{l}\text { Continuously support the } \\
\text { importance of linking the } \\
\begin{array}{l}\text { economic and environmental } \\
\text { goals of the company }\end{array}\end{array}$ & 4 & 4 & 3,93 & 3 & 5 \\
\hline $\begin{array}{l}\text { Raise awareness of green } \\
\text { issues in society }\end{array}$ & 4 & 4 & 4,46 & 4 & 5 \\
\hline $\begin{array}{l}\text { Provide information on the so- } \\
\text { called green problems for the } \\
\text { company's management }\end{array}$ & 4 & 4 & 4,72 & 4 & 5 \\
\hline $\begin{array}{l}\text { Actively advise the company's } \\
\text { stakeholders (company } \\
\text { management) on } \\
\text { environmental issues }\end{array}$ & 5 & 5 & 4,81 & 4 & 5 \\
\hline $\begin{array}{l}\text { Give impulses and coordinate } \\
\text { the implementation of "green } \\
\text { goals" into company processes }\end{array}$ & 3 & 3 & 3,16 & 3 & 4 \\
\hline \hline
\end{tabular}

Source: own processing 


\section{Application of ecological aspects in management}

Other questions were aimed at finding out how companies solve specific approach to green issues. Therefore, in the next question, we found out whether the surveyed companies take into account environmental aspects in management. Of the 67 agricultural holdings, 40 companies answered positively. In the remaining 27 companies, environmental targets are not defined at all. From interviews with selected business entities, we found that many companies implement environmental measures only if they have an economic benefit, e.g. elevating the image of society Rajnoha et al. (2019, p. 61) confirm that nowadays, customers are increasingly looking at sustainability aspects, and this situation to become even more intense in the future.

In order to determine the dependence, we performed a Chi-square test in which we examined whether the size of the company, the legal form, the length of operation in the market and foreign capital participation had an impact on the respondents' answers. From the analysis, we found that whether companies solve environmental management problems depends on the participation of foreign capital in the company, so we accept hypothesis H1.

\section{Table 4. Results of Chi-square test}

\begin{tabular}{ll}
\hline \hline Chi-square test & \\
\hline $\mathrm{p}$ value & 0,030157 \\
\hline \hline
\end{tabular}

Source: own processing

Respondents who answered positive to the previous question were further asked in which processes they pay the most attention to environmental goals.

Table 5. Processes that take into account environmental objectives

\begin{tabular}{lccccc}
\hline \hline & Modus & Median & Average & Min & Max \\
\hline \hline Strategic planning & 4 & 4 & 4,09 & 3 & 5 \\
\hline Operational planning & 3 & 3 & 2,91 & 2 & 5 \\
\hline Budgeting & 2 & 2 & 1,55 & 0 & 2 \\
\hline Costing & 2 & 2 & 1,66 & 0 & 2 \\
\hline Reporting & 4 & 4 & 3,81 & 2 & 5 \\
\hline Risk management & 3 & 3 & 2,76 & 1 & 3 \\
\hline Investing & 4 & 4 & 3,78 & 3 & 4 \\
\hline Business consulting & 3 & 3 & 2,67 & 1 & 4 \\
\hline \hline
\end{tabular}

Source: own processing 
From the questionnaire answers, the respondents gave the highest weight to strategic planning, reporting and investment. On the contrary, they take the least into account environmental objectives when calculating costs.

Table 6. Green controlling tools applied in agricultural enterprises

\begin{tabular}{lccccc}
\hline \hline & Modus & Median & Average & Min & Max \\
\hline \hline Life cycle assessments & 0 & 0 & 0,48 & 0 & 1 \\
\hline $\begin{array}{l}\text { Ecologically oriented portfolio } \\
\text { analysis }\end{array}$ & 2 & 2 & 2,03 & 1 & 4 \\
\hline $\begin{array}{l}\text { Creating a budget for the } \\
\text { environment }\end{array}$ & 2 & 2 & 2,04 & 1 & 3 \\
\hline Cross-impact analysis & 0 & 0 & 0,19 & 0 & 1 \\
\hline Environmental audit & 4 & 4 & 3,36 & 1 & 5 \\
\hline Environmental costing & 2 & 2 & 1,97 & 1 & 3 \\
\hline Material and energy balances & 2 & 2 & 2,03 & 1 & 3 \\
\hline $\begin{array}{l}\text { Value chain analysis focused } \\
\text { on ecology }\end{array}$ & 0 & 1 & 1,19 & 0 & 3 \\
\hline $\begin{array}{l}\text { Ecologically oriented early } \\
\text { warning systems }\end{array}$ & 0 & 0 & 0,24 & 0 & 1 \\
\hline \hline
\end{tabular}

Source: own processing

Among the tools of green controlling, the most frequently applied in agricultural enterprises is environmental audit, creation of a budget for the environment and material and energy balances. The tools of green controlling are also highlighted by Rusko et al. (2014, p. 491), who confirm that environmental audit can reveal insufficient compliance with environmental duties imposed on companies within their individual operative units of production. From an interview with representatives of selected agricultural enterprises, we found out that many green controlling tools are unknown. On the other side, Marsina et al. $(2019$, p. 772$)$ state that the pro-environmental behavior of companies can be influenced and that companies with limited resources should focus on organizational norms and standards and employee training and development to achieve the greatest positive effect on pro-environmental behavior.

\section{Conclusion}

The results of the empirical research show that most agricultural enterprises do not have a deeper knowledge of the ecological direction and management of the enterprise and the importance of green controlling. As regards the implementation of its instruments, agricultural holdings are lagging behind. Environmental objectives in business are usually taken into account only if they have an economic benefit, such as increasing the company's image. Environmental aspects are most 
often implemented in the field of strategic planning. The most applied green controlling tool is environmental audits. Many of the tools covered by green controlling are unknown on farms. Farms are resistant to any changes and are reluctant to change existing practices and methods. At the same time, farm managers think that the implementation of environmental controlling tools will be connected with high costs. This also follows from the fact that in general there are certain gaps in the understanding of the concept of controlling, so it would be appropriate to provide more extensive training and seminars on this issue. In practice, green controlling cannot be implemented overnight. The implementation of the corresponding green controlling tools consists in the identification of key problems of sustainable management and the systematic integration of environmental goals into the corporate strategy.

Promoting ecological aspects into entrepreneurship on agricultural holdings is a challenging process. Future research should focus on solving the problems of measuring and evaluating environmental aspects and integrating them into existing IT systems and business tools. The limiting factor of the research is the considerable ignorance of the agricultural holdings representatives about the ecological aspects entering into the management of the company, as well as their negative approach.

\section{Acknowledgements}

This paper was supported by the Grant Agency of the Slovak University of Agriculture in Nitra under project GA 30/2019.

\section{References}

1. Bedenik N.O., Prebežac D., Strugar I., Barišić P. (2019), The Challenges of Controlling and IT Support in Non-financial Reporting. „International Journal of Industrial Engineering and Management (IJIEM)", no. 1, vol. 10, pp. 21-29. http://doi.org/10.24867/IJIEM-2019-1-021

2. Dobrovič J. (2015), Regional Development of Small and Medium-Sized Enterprises (smes) in the Prešov Region with Focus on Tourism, „Procedia Economics and Finance”, vol. 34, pp. 594-599. https://doi.org/10.1016/S2212-5671(15)01673-1

3. Greiling D., Ther D. (2010), Leistungsfähigkeit des Sustainable Value-Ansatzes als Instrument des Sustainability Controlling, „Corporate Sustainability”, pp. 37-67. Gabler Verlag. https://doi.org/10.1007/978-3-8349-8991-8_3

4. Günther E., Günther T., Endrikat, J. (2018), Mehr Umwelt ins Controlling!, „Controlling \& Management Review”, no. 5, vol. 62, pp. 34-41. https://doi.org/10.1007/s12176-018-0031-0

5. Horváth P. (2018), ,, Green “ Controlling - Umweltorientierung in der Unternehmenssteuerung. In Rechnungslegung, Steuern, Corporate Governance, Wirtschaftsprüfung und Controlling, pp. 611621, Springer Gabler, Wiesbaden. https://doi.org/10.1007/978-3-658-21634-4_35

6. Isensee J., Michel U., (2011), Green Controlling - Die Rolle des Controllers und aktuelle Entwicklungen in der Praxis, „Controlling”, vol. 23, pp. 436-442.

7. Marsina S., Hamranova A., Hrivikova T., Bolek V., Zagorsek B. (2019), How can project orientation contribute to pro-environmental behavior in private organizations in Slovakia, „Journal of cleaner production”, vol. 231, pp.772-782. https://doi.org/10.1016/j.jclepro.2019.05.186 
8. Michel U., Isensee J., Stehle A. (2014), Sustainability Controlling: Planung, Steuerung und Kontrolle der Realisierung der Nachhaltigkeitsstrategie. In CSR und Finance, pp. 97-111, Springer Gabler, Berlin, Heidelberg. https://doi.org/10.1007/978-3-642-54882-6_6

9. Mura L., Buleca J. (2014), Trends in international business of the Slovak small and medium food enterprises, „Procedia-Social and Behavioral Sciences”, vol. 110, pp. 905-912. https://doi.org/10.1016/j.sbspro.2013.12.936

10. Pabian A., Pabian B. (2014). Sustainable management of an enterprise: functional approach, „Polish Journal of Management Studies”, no.1, vol. 10., pp. 98-107.

11. Păunică M., Mocanu M. (2017), Green controlling-concept and practice, „Proceedings of the International Conference on Business Excellence", no. 1, vol. 11, pp. 1137-1145. https://doi.org/10.1515/picbe-2017-0117

12. Pletnev D., Barkhatov V. (2016), Business success of small and medium sized enterprises in Russia and social responsibility of managers, „Procedia-Social and Behavioral Sciences”, vol. 221, pp. 185-193. https://doi.org/10.1016/j.sbspro.2016.05.105

13. Rajnoha R., Lesnikova P., Stefko, R., Schmidtova J., Formanek I. (2019), Transformations in Strategic Business Planning in the Context of Sustainability and Business Goals Setting, „Transformations in Business \& Economics”, no. 2, vol. 18, pp.44-66.

14. Rusko M., Sablik J., Marková P., Lach M., Friedrich S. (2014), Sustainable development, quality management system and environmental management system in Slovak Republic, „Procedia Engineering",vol. 69, pp.486-491. https://doi.org/10.1016/i.proeng.2014.03.016

15. Stanciu R.D. (2014), Do Romanian small and medium-sized enterprises use performance management? An empirical study, „Procedia Social and Behavioral Sciences”, vol. 124, pp. 255262. https://doi.org/10.1016/j.sbspro.2014.02.484

16. Vasile E., Man M. (2012), Current dimension of environmental management accounting, „Procedia-Social and Behavioral Sciences”, vol. 62, pp. 566-570. https://doi.org/10.1016/j.sbspro.2012.09.094

17. Vitezic N., Vitezic V. (2015), A conceptual model of linkage between innovation management and controlling in the sustainable environment, „Journal of Applied Business Research”, no. 1, vol. 31, pp. 175. https://doi.org/10.19030/jabr.v31i1.8999

18. Yoshino N., Taghizadeh-Hesary, F. (2019), Optimal credit guarantee ratio for small and mediumsized enterprises' financing: Evidence from Asia, „Economic Analysis and Policy”, vol. 62, pp. 342-356. https://doi.org/10.1016/j.eap.2018.09.011 